\title{
Pengujian Kapasitas Antioksidan Wedang Tahu dalam Rangka Meningkatkan Mutu Fungsionalnya
}

\author{
Determination of Antioxidant Capacity of Soft Tofu Dessert \\ in Order to Improve its Functional Quality
}

\author{
Nurheni Sri Palupi ${ }^{1,2)^{*}}$ dan Rachmat Widyanto ${ }^{3)}$ \\ 1) Departemen Ilmu dan Teknologi Pangan, Fakultas Teknologi Pertanian, Institut Pertanian Bogor, Bogor \\ 2) Southeast Asian Food and Agricultural Science and Technology Center, LPPM, Institut Pertanian Bogor, Bogor \\ 3) Program Studi Ilmu Pangan, Sekolah Pascasarjana, Institut Pertanian Bogor, Bogor
}

\begin{abstract}
Efforts to prevent and overcome various degenerative diseases can be realized by developing functional foods that are known as natural or processed foods containing bioactive components that have the potential to improve health status. One of whole foods that has potency to be developed as functional food is soft tofu dessert. Soft tofu dessert has two main components which are soft tofu and ginger drink. However, there is lack of references providing the evidence of the characteristics and health benefit or soft tofu dessert. This study provide data to support the development of soft tofu dessert as a whole food that has optimum characteristic and contains benefit for health as well. The research objectives were to test radical scavenging capacity of soft tofu dessert and its component by implementing DPPH method. Antioxidant capacity of the samples was observed by using DPPH method $(517 \mathrm{~nm})$. Ranges of concentration were observed to determine IC50 of each sample. IC50 value presents the inhibition of 50\% DPPH radical by samples. The values of IC50 for ginger water extract, ginger drink, soft tofu, and soft tofu dessert were $1592.40 \pm 22.30 \mathrm{ppm}, 2764.26 \pm 90.29 \mathrm{ppm}, 24657.50 \pm 2483.11 \mathrm{ppm}$, and $3356.04 \pm 415.54 \mathrm{ppm}$ respectively. This result showed the best radical scavenging capacity was ginger water extract $>$ ginger drink $>$ soft tofu dessert, and > soft tofu. Soft tofu dessert performed better scavenging capacity than soft tofu itself, but still performed the lower capacity compared to ginger water extract and ginger drink.
\end{abstract}

Keywords: DPPH, ginger drink, ginger water extract, soft tofu, soft tofu dessert

\begin{abstract}
Abstrak. Dalam upaya pencegahan dan penanggulangan berbagai penyakit degeneratif, pangan fungsional yang dikenal dapat berupa pangan alami atau olahan dengan kandungan komponen bioaktifnya berpotensi mampu meningkatkan status kesehatan. Wedang tahu yang merupakan pangan tradisional berpotensi untuk dikembangkan sebagai pangan fungsional. Produk pangan tersebut terdiri dari komponen utama yang berupa tahu sutera dan kuahnya yang berupa minuman jahe. Belum banyak penelitian dilakukan untuk mengeksplorasi potensi wedang tahu sebagai salah satu pangan sehat, terutama karakteristik fungsionalnya, yang diantaranya adalah kapasitasnya sebagai antioksidan. Untuk itu, penelitian ini bertujuan menyediakan data kapasitas antioksidan untuk mendukung pengembangan wedang tahu sebagai pangan fungsional sehingga dapat memberikan nilai tambah. Aktivitas antioksidan wedang tahu dan komponennya ditentukan dengan menguji kemampuannya dalam menghambat senyawa radikal bebas menggunakan metode DPPH. Kapasitas antioksidan ditunjukkan dengan nilai IC50 yang meng-gambarkan terjadinya penghambatan sebesar 50\% senyawa radikal DPPH oleh sampel pada konsentrasi tertentu. Hasil penelitian menunjukkan bahwa nilai IC50 sebesar $1592.40 \pm 22.30 \mathrm{ppm}$ untuk air ekstrak jahe, $2764.26 \pm 90.29 \mathrm{ppm}$ untuk minuman jahe, $24657.50 \pm 2483.11 \mathrm{ppm}$ untuk tahu sutera, dan $3356.04 \pm 415.54 \mathrm{ppm}$ untuk wedang tahu. Efektivitas penghambatan terhadap 50\% senyawa radikal bebas yang paling tinggi adalah air ekstrak jahe, diikuti dengan minuman jahe, wedang tahu dan tahu sutera. Wedang tahu menunjukkan kapasitas penghambatan radikal bebas yang lebih efektif dibandingkan tahu sutera meskipun kurang efektif jika dibandingkan dengan air ekstrak jahe dan minuman jahe. Berdasarkan persamaan garis pada kurva IC50, diperkirakan besaran penghambatan terhadap senyawa radikal bebas satu porsi wedang tahu dan minuman jahe adalah sebesar $50 \%$.
\end{abstract}

Kata Kunci: air ekstrak jahe, DPPH, minuman jahe, tahu sutera, wedang tahu

Aplikasi Praktis: Melalui kegiatan penelitian ini dapat diperoleh informasi mengenai nilai tambah produk tradisional wedang tahu sebagai salah satu produk pangan sehat. Pengujian aktivitas antikosidan wedang tahu dan komponen-komponennya merupakan salah satu upaya untuk memberikan nilai tambah pada pangan tradisional yang bermanfaat untuk kesehatan. Penelitian ini juga menggambarkan bahwa satu porsi wedang tahu memiliki kapasitas penghambatan terhadap radikal bebas yang dapat mengganggu kesehatan.

Korespondensi: hnpalupi@apps.ipb.ac.id 


\section{PENDAHULUAN}

European Commission (EC) mendefinisikan pangan fungsional sebagai pangan yang bermanfaat terhadap salah satu atau lebih fungsi kesehatan tubuh manusia selain kecukupan gizinya, dengan cara meningkatkan status kesehatan dan kebugaran serta mengurangi risiko penyakit. Pangan fungsional tersebut dikonsumsi sebagai bagian dari pola pangan pada umumnya, dan bukan berupa pil, kapsul, atau bentuk suplemen lainnya (EC 2010). Kedelai dan produk olahannya telah dikenal sebagai pangan yang dapat meningkatkan kesehatan (health-promoting food), sedangkan jahe telah lama dimanfaatkan untuk mengatasi berbagai macam penyakit. Produk hasil olahan kedelai dan jahe belum semua dipelajari potensi sifat fungsionalnya, termasuk wedang tahu. Wedang tahu merupakan salah satu produk olahan kedelai yang berupa tahu sutera dengan penambahan kuah jahe. Tahu sutera (douhua) dihasilkan dengan cara menggumpalkan susu kedelai dengan menggunakan penggumpal (koagulan) tanpa adanya proses penekanan (Shurtleff dan Aoyagi 2013).

Suatu produk pangan olahan berbasis kedelai tentunya akan mengandung senyawa antioksidan yang berasal dari bahan bakunya, yaitu kedelai. Oleh karena itu, konsumsi produk pangan berbasis kedelai akan memberikan manfaat dari senyawa antioksidan yang terkandung di dalamnya, meskipun aktivitasnya tidak akan sama akibat adanya proses pengolahan. Sebagai contoh misalnya, senyawa fenolik seperti asam fenolat dan kelompok flavonoid (flavanon, flavonol, dan flavanol) terkandung di dalam matriks susu kedelai dan diketahui dapat diserap dalam jumlah yang cukup atau memiliki bioakses yang cukup dapat berkontribusi terhadap kesehatan (Rodríguez-Roque et al. 2013). Tahu juga memiliki aktivitas antioksidan yang bervariasi. Tahu yang digumpalkan dengan menggunakan kalsium, alum, dan whey-nya, memiliki nilai total fenol, kemampuan menangkap radikal bebas dari senyawa fenolik, dan kemampuan reduksi dari senyawa fenolik yang berbedabeda. Yakubu et al. (2013) menyimpulkan bahwa tahu yang diperoleh dari bahan koagulan yang berbeda memiliki kemampuan menangkap radikal bebas dari senyawa fenolik yang lebih tinggi dibandingkan dengan kemampuan mereduksinya. Jahe mengandung gingerol juga diketahui memiliki sifat antioksidan yang kuat baik in vitro maupun in vivo, serta efek antiinflamasi dan antiapoptosis (Kim et al. 2007). Total fenol dari ekstrak alkohol jahe diketahui mencapai $870.1 \mathrm{mg} / \mathrm{g}$ ekstrak keringnya. Efek penghambatan terhadap radikal DPPH mencapai $90.1 \%$ dan mampu melampaui efek antioksidasi kontrol berupa butylated hydroxytoluene (BHT). Selain itu, konsentrasi IC50 dari jahe dalam aktivitas penghambatan radikal DPPH mencapai $0.64 \mu \mathrm{g} / \mathrm{mL}$ (Stoilova et al. 2007).

Istilah 'kapasitas antioksidan' terlihat lebih leluasa penggunaannya karena meliputi efisiensi, kekuatan, parameter, potensial, dan aktivitas antioksidan. Oleh karena itu, istilah 'kapasitas antioksidan' dapat digunakan dengan merujuk pada hasil pengujian menggunakan metode yang berbeda, baik metode transfer atom hidrogen (hydrogen atom transfer/HAT assay) maupun metode transfer elektron (electron transfer/ET assay). Metode HAT meliputi metode Oxygen Radical Absorbance Capacity (ORAC), metode Total Peroxyl Radical-trapping Antioxidant Parameter (TRAP), metode 2,2'-azobis (2-amidinopropane) hydrochloride (AAPH), dan metode bleaching $\beta$-carotene. Sedangkan metode ET meliputi metode 2,2'-Azinobis-(3-ethylbenzothiazoline6-sulfonic acid) (ABTS), Tro-lox-Equivalent Antioxidant Capacity (TEAC), 2,2-di(4-tert-octylphenyl)-1-picrylhydrazyl (DPPH), Ferric Reducing Antioxidant Power (FRAP), dan Cupric Reducing Antioxidant Capacity (CUPRAC) (Aspak et al. 2013). Penggunaan istilah kapasitas antioksidan lebih merujuk kepada metode uji antioksidan konvensional, sedangkan istilah aktivitas antioksidan merujuk kepada metode yang berprinsip pada pengukuran laju aksi antioksidan atau kinetikanya (Han et al. 2012). Penelitian ini bertujuan untuk menguji potensi wedang tahu dan komponennya sebagai antioksidan yang mampu menghambat senyawa radikal bebas menggunakan metode DPPH.

\section{BAHAN DAN METODE}

\section{Bahan}

Bahan utama yang digunakan dalam penelitian ini antara lain kedelai GMO merek Bola (Gerbang Cahaya Utama-Rumah Tempe Indonesia), CaSO4 (SGP-Setia Guna), jahe merah (Zingiber officinale var. Rubrum) (Balitro, Bogor), gula merah (Alfamidi), gula pasir putih (Gulaku), dan air minum (Aqua, Danone). Bahan kimia yang digunakan yaitu akuabides, etanol, quersetin, asam askorbat, molekul 2,2-diphenyl-1-picrylhydrazyl (DPPH - Sigma Aldrich Cat. No 1898-66-4) dan lain-lain.

\section{Preparasi sampel}

Pada penelitian ini digunakan empat macam sampel, yaitu air ekstrak jahe (AJ), minuman jahe (KJ), tahu sutera (TL), dan wedang tahu (WT). Persiapan sampel untuk menentukan apakah wedang tahu secara utuh atau komponennya yang berkontribusi dalam menentukan kapasitas antioksidan, dilakukan dengan mengacu pada Widyanto et al. (2017). Tahu sutera dengan formula optimum dibuat dengan merendam kedelai $(330 \mathrm{~g})$ dalam air (1:1) selama 6 jam kemudian dicuci dan dihilangkan kulitnya. Setelah itu, kedelai digiling menggunakan blender selama 1 menit dan ditambahkan air sebanyak 1 L. Hancuran kedelai tersebut lalu disaring menggunakan kain saring sehingga didapatkan susu kedelai. Susu kedelai direbus $\left(90^{\circ} \mathrm{C}, 10\right.$ menit) dan dihilangkan busa yang timbul. Kemudian, susu kedelai dituangkan dengan segera pada wadah yang telah ditambahkan CaSO4 (SGPSetia Guna) dengan konsen-trasi $10 \mathrm{~g}$ ke dalamnya. Campuran tersebut didiamkan pada suhu ruang sehingga tahu sutera terbentuk. Adapun untuk membuat minuman jahe, rimpang jahe merah dicuci dan diparut tanpa 
menghilangkan kulitnya terlebih dahulu. Komposisi yang digunakan adalah $230 \mathrm{~g}$ jahe merah, $111 \mathrm{~g}$ gula merah, 259 g gula pasir putih, dan $1 \mathrm{~L}$ air minum. Campuran tersebut direbus $\left(90^{\circ} \mathrm{C}, 10\right.$ menit) dan disaring menggunakan kain saring sehingga didapatkan minuman jahe. Sampel air ekstrak jahe, diperoleh dari proses ektraksi jahe dengan mengunakan prosedur pembuatan minuman jahe, namun tidak dilakukan penambahan gula. Sampel wedang tahu dibuat dengan mengombinasikan sebanyak $80 \mathrm{~g}$ tahu sutera dan $200 \mathrm{~mL}$ minuman jahe.

Sampel yang telah dibuat tersebut kemudian dikeringbekukan menggunakan freeze dryer selama kurang lebih 96 jam. Sampel yang diperoleh berupa bubuk (powder) dengan dua ulangan, selanjutnya dimasukkan ke dalam wadah yang kedap air dengan diletakkan gel silika di dalamnya. Sampel dibuat menjadi larutan stok dengan pelarut akuabides berdasarkan perhitungan pengenceran darah dan disentrifus (3000 rpm, 30 menit). Sampel kemudian diambil supernatannya dan ditempatkan dalam wadah gelap.

\section{Pengujian kapasitas penghambatan radikal DPPH (Aranda et al. 2011)}

Persiapan larutan stok DPPH $125 \mu \mathrm{M}$ dilakukan dengan melarutkan sebanyak $2.5 \mathrm{mg}$ DPPH ke dalam etanol p.a dalam labu ukur dan ditepatkan hingga volume $50 \mathrm{~mL}$ dan selanjutnya labu ukur dilapisi aluminium foil. Standar vitamin $\mathrm{C}$ dan quersetin ditimbang masingmasing ditimbang sebanyak $10 \mathrm{mg}$. Kemudian dilarutkan dengan akuabides sebanyak $1 \mathrm{~mL}$. Disonikasi hingga larut, kemudian divorteks. Larutan standar dibuat menjadi beberapa konsentrasi $(0.625,1.25,2.5,5$, dan 10 ppm). Sampel dibuat menjadi beberapa konsentrasi (150, $500,1500,5000,15000$, dan 50000 ppm) yang diambil berdasarkan pertimbangan agar memenuhi semua rentang konsentrasi dari konsentrasi sampel satu porsi setelah dihitung menggunakan perhitungan pengenceran darah.

Sampel yang berupa supernatan larutan stok yang telah disentrifus pada tahap preparasi, dimasukkan ke dalam microplate (microplate 96 well Falcon, USA) sebanyak $100 \mu \mathrm{L}$. Selanjutnya ditambahkan $100 \mu \mathrm{L}$ DPPH ke dalam sampel, sedangkan untuk kontrol negatif hanya ditambahkan $100 \mu \mathrm{L}$ akuabides ke dalam sampel. Setelah itu, inkubasi dilakukan pada suhu ruang pada bebas cahaya (gelap) selama 30 menit. Pembacaan intesitas warna yang terbentuk dilakukan menggunakan spektrofotometer (Epoch Biotech Instrument, USA) pada panjang gelombang $517 \mathrm{~nm}$. Larutan blanko yang digunakan berupa $100 \mu \mathrm{L}$ akuabides dan ditambahkan DPPH sebanyak $100 \mu \mathrm{L}$, sedangkan untuk kontrol negatif digunakan $200 \mu \mathrm{L}$ akuabides. Kapasitas penghambatan radikal bebas dihitung menggunakan rumus sebegi berikut:

Kapasitas Penghambatan Radikal Bebas (\%) $=($ A - B $) / A \times 100$

Dimana A adalah absorbansi dari larutan blanko (DPPH dan etanol) dan B adalah absorbansi sampel (DPPH, etanol, dan sampel). Nilai absorbansi sampel dikurangi dengan absorbansi koreksi yang merupakan nilai absorbansi dari sampel saja. Nilai persentasi inhibisi tersebut diplot ke dalam kurva sebagai variabel y dan konsentrasi sampel sebagai variabel x. Persamaan garis dilakukan proses fitting dengan menentukan persamaan garis yang digunakan berdasarkan nilai R2 yang paling tinggi. Nilai kapasitas dinyatakan dalam persen IC50 (konsentrasi efektif dari sampel yang mampu menghambat 50\% radikal DPPH). Nilai IC50 dihitung berdasarkan persamaan garis yang didapatkan dengan memasukkan nilai 50 sebagai variabel y dan mencari nilai variabel $\mathrm{x}$ sebagai konsentrasi sampel yang dicari.

\section{HASIL DAN PEMBAHASAN}

\section{Kapasitas penghambatan radikal bebas}

Penghambatan radikal bebas dapat diketahui dengan menggunakan reagen 2,2-diphenyl-1-picrylhydrazyl (DPPH). Metode DPPH banyak diterapkan secara rutin dalam pengujian kemampuan penghambatan (inhibisi) dari komponen murni maupun ekstrak karena relative mudah, cepat, dan terjangkau (Shalaby dan Shanab 2013). Penghambatan DPPH dapat disebabkan oleh adanya komponen antioksidan di dalam matriks sampel. Besarnya penghambatan radikal bebas dapat dilihat dari nilai Inhibition Concentration 50 (IC50) atau disebut juga Effective Concentration 50 (EC50). Nilai IC50 merupakan nilai hasil interpolasi persamaan yang didapatkan dengan mengukur konsentrasi sampel yang diperlukan untuk menghambat radikal DPPH sebesar 50\%. Semakin rendah nilai IC50 maka semakin efektif sampel dalam menghambat senyawa radikal DPPH dan sebaliknya. Nilai IC50 yang didapat tergantung pada pemilihan persamaan yang disajikan pada analisis model regresi (Chen et al. 2013). Pada penelitian ini, semua kurva hasil uji penghambatan radikal bebas baik oleh sampel maupun standar menunjukkan jenis kurva logaritmik, kecuali pada sampel tahu sutera. Jenis kurva tersebut diputuskan berdasarkan nilai koefisien determinasi (R2) yang tinggi (mendekati 1) dari masing-masing kurva. Kurva dan persamaan dari standar dapat dilihat pada lampiran 3 dan sampel dapat dilihat pada Gambar 1.

Sifat penghambatan radikal bebas dapat dipengaruhi jenis pelarut yang digunakan, dalam penelitian ini digunakan pelarut air untuk mengekstrak jahe. Standar vitamin $\mathrm{C}$ digunakan untuk mewakili komponen yang larut dalam air, sedangkan quersetin untuk mewakili komponen yang tidak larut air. Nilai IC50 yang tinggi diduga juga disebabkan oleh jenis pelarut yang digunakan. Pada penelitian ini digunakan akuabides sebagai pelarut sampel, sedangkan untuk melarutkan DPPH tetap digunakan etanol.

Vayuphard dan Laksanalamai (2012) melaporkan bahwa nilai IC50 sampel biji anggur yang dilarutkan dalam air lebih tinggi $(520 \mathrm{ppm})$ dibandingkan sampel yang dilarutkan dalam larutan etanol (251.33-353.33 ppm) dan larutan aseton (210.67-394.33 ppm). Boly et al. (2016) mendapatkan nilai IC50 yang rendah dengan 
menggunakan pelarut metanol pada pengujian inhibisi DPPH oleh ekstrak daun Agelanthus dodoneifolius (8.28-13.20 ppm).

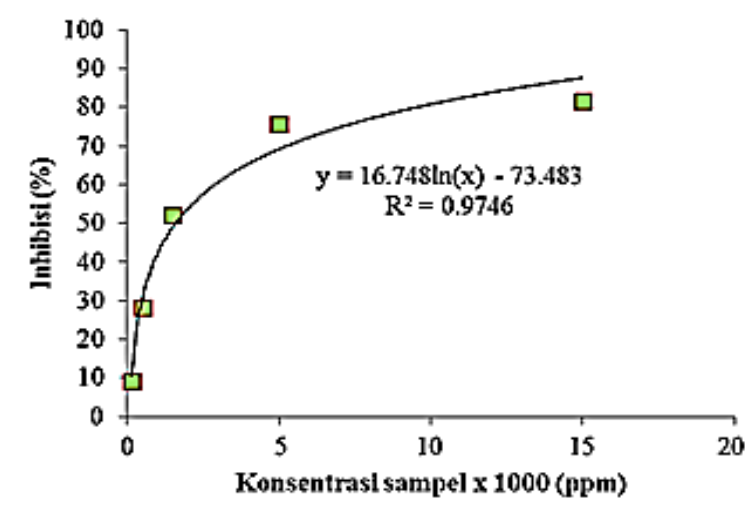

(A)

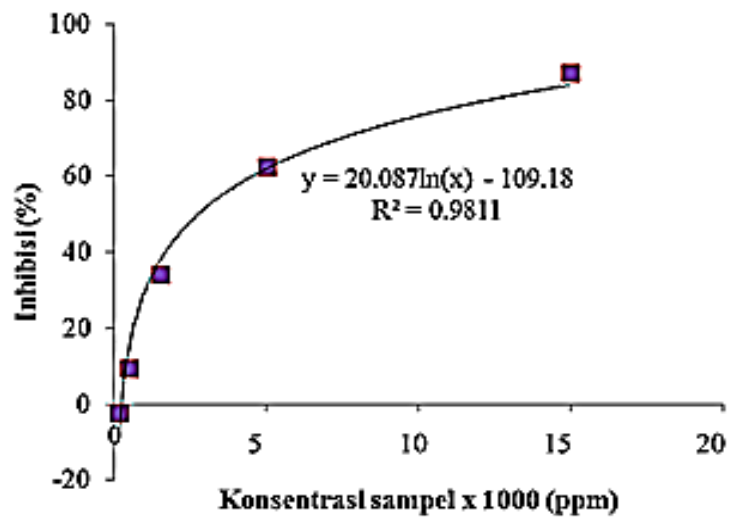

(B)
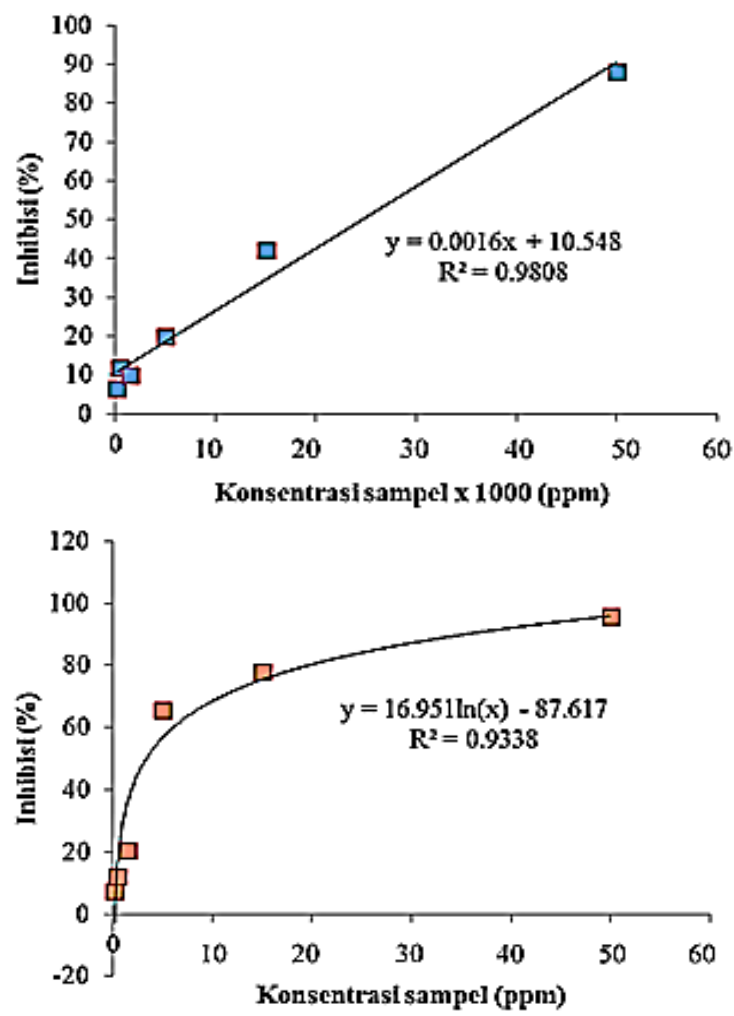

Gambar 1. Penghambat radikal bebas oleh sampel : a) air ekstrak jahe, b) minuman jahe, c) tahu sutera, dan d) wedang tahu

Yeh et al. (2014) menambahkan bahwa efek antioksidan dari ekstrak etanol jahe diketahui lebih efektif daripada ekstrak airnya. Dalam proses pembuatannya, pelarut yang digunakan untuk membuat sampel adalah air. Pelarut air digunakan sebagai pendekatan uji sifat inhibisi radikal bebas wedang tahu sebagai pangan utuh. Oleh karena itu, nilai IC50 dari keempat sampel menunjukkan nilai yang lebih tinggi dibandingkan dengan nilai IC50 dari penelitian yang lain yang diekstrak menggunakan pelarut selain air. Seperti telah dijelaskan sebelumnya, semakin rendah nilai IC50 maka semakin efektif sampel dalam menghambat radikal DPPH dan sebaliknya. Dengan demikian maka meskipun wedang tahu dan komponennya menunjukkan kapasitas antioksidan, namun efektivitasnya masih lebih rendah dibandingkan yang diekstrak mengganakan pelarut selain air, seperti etanol.

Gambar 2 menunjukkan bahwa nilai IC50 dari keempat sampel secara berturut-turut adalah sebesar 1592.40 ppm (air ekstrak jahe), 2764.26 ppm (minuman jahe), $24657.50 \mathrm{ppm}$ (yahu sutera), dan 3356,04 ppm (wedang tahu). Berdasarkan data dan nilai standar deviasi pada Gambar 2, dapat diketahui bahwa nilai IC50 wedang tahu lebih rendah dibandingkan tahu sutera, meskipun nilai IC50 wedang tahu lebih tinggi dibandingkan air ekstrak jahe dan minuman jahe. Dengan demikian, kapasitas penghambatan radikal DPPH wedang tahu dapat dikatakan masih lebih baik jika dibandingkan dengan tahu sutera. Dengan demikian maka ditinjau dari kapasitas antioksidannya, wedang tahu secara utuh lebih baik dibandingkan tahu sutera karena menunjukkan kapasitas penghambatan terhadap radikal DPPH yang lebih efektif. Selain itu juga tampak adanya peranan dari komponen jahe dalam meningkatkan kapasitas penghambatannya.

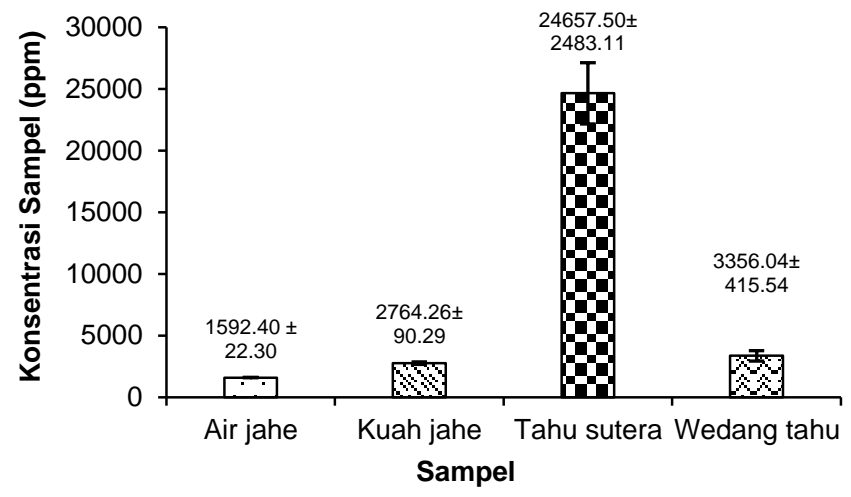

Gambar 2. Nilai IC50 kapasitas antioksidan dari sampel air ekstrak jahe, minuman jahe, tahu sutera, dan wedang tahu

Nilai IC50 wedang tahu lebih rendah dan berbeda nyata $(\mathrm{p}<0.05)$ dengan tahu sutera, tetapi tidak berbeda nyata $(p>0.05)$ dengan air ekstrak jahe dan minuman jahe. Komponen utama dalam wedang tahu, yaitu tahu sutera dan minuman jahe diduga menunjukkan efek sinergis terhadap penghambatan radikal bebas DPPH. Komponen bioaktif yang terdapat di dalam matriks wedang tahu diduga berinteraksi sehingga mengakibatkan efisiensi penghambatan terhadap radikal bebas meningkat. Dugaan adanya interaksi tersebut didukung dengan penelitian Rodríguez-Roque et al. (2013) yang menunjukkan 
adanya kemampuan antioksidan dari saponin yang bersifat sinergis terhadap komponen bioaktif lainnya yang memiliki donor hidrogen pada molekulnya seperti komponen fenol pada minuman sari kedelai. Selain komponen fenolik, isoflavon juga diduga berpengaruh terhadap interaksi antar komponen yang sinergis. Kandungan isoflavon aglikon seperti daidzein dan genistein diketahui juga meningkat pada tahu telur (Murad et al. 2013).

Kandungan tanin di dalam jahe diketahui menunjukkan kemampuan mereduksi dan menghambat radikal bebas yang lebih baik dibandingkan komponen flavonoidnya (Shirin dan Jamuna 2010). Potensi sinergisitas antioksidan juga ditunjukkan oleh ekstrak air dari campuran jahe, teh, lada hitam, dan tulsi meskipun masih lebih rendah dari ekstrak metanolnya. Sinergisitas tersebut terlihat dari aktivitas antioksidan yang paling tinggi dibandingkan dengan individual atau campuran lainnya (Gupta et al. 2014). Minuman campuran dari jahe, coklat, dan bunga Hibiscus memperlihatkan sifat antioksidan yang tinggi baik pada ekstrak air dingin atau air panasnya, meskipun penambahan jahe dinilai tidak mempengaruhi peningkatan aktivitas antioksidan secara signifikan (Awe et al. 2013). Efek sinergis antioksidan dalam pangan lebih efektif dibandingkan dengan kombinasi dari bermacam senyawa antioksidan tunggal hasil isolasi (Giada 2014). Minuman jahe sebagai salah satu komponen wedang tahu diduga berperan dalam memberikan efek antioksidan yang sinergis. Penelitian serupa menunjukkan penambahan jahe pada produk es krim susu kedelai dapat memberikan flavor khas jahe dan sekaligus meningkatkan aktivitas antioksidan, kemampuan penghambatan radikal bebas, dan kemampuan mereduksi Fe (Wangcharoen 2012).

Besaran penghambatan radikal bebas wedang tahu dan komponennya diperkirakan berdasarkan persamaan kurva IC50 masing-masing sampel. Nilai konsentrasi sampel yang didapat dari perhitungan berdasarkan pengenceran darah disimulasikan sebagai komponen variabel bebas (x) dari persamaan yang didapat dari uji penghambatan radikal bebas. Perhitungan tersebut menghasilkan nilai \% penghambatan atau inhibisi radikal bebas dari konsentrasi satu porsi sampel. Nilai persentase inhibisi radikal bebas disimulasikan sebagai variabel terikat (y) (Tabel 1).

Tabel 1. Nilai perkiraan besaran penghambatan radikal bebas untuk tiap 1 porsi sampel

\begin{tabular}{lc}
\hline \multicolumn{1}{c}{ Sampel } & Penghambatan Radikal Bebas (\%) \\
\hline Air ekstrak jahe & $45.61 \pm 1.08$ \\
Minuman jahe & $80.65 \pm 3.91$ \\
Tahu sutera & $13.29 \pm 0.11$ \\
Wedang tahu & $74.66 \pm 5.53$ \\
\hline
\end{tabular}

Bila dibandingkan berdasarkan nilai IC50, sampel yang paling efisien menghambat radikal bebas secara berturut-turut adalah : air ekstrak jahe > minuman jahe > wedang tahu > tahu sutera. Bila dilihat dari efektifitas penghambatan radikal bebas oleh satu porsi sampel, hasil simulasi menunjukkan bahwa satu porsi wedang tahu dan minuman jahe masing-masing diduga mampu menghambat lebih dari $50 \%$ radikal bebas, sedangkan satu porsi air ekstrak jahe dan tahu sutera menghambat kurang dari $50 \%$ radikal bebas. Hal tersebut dikarenakan nilai konsentrasi sampel (x) yang berbeda dengan nilai IC50 sampel masing-masing. Sebagai contoh, sampel air ekstrak jahe dapat menghambat $50 \%$ radikal bebas pada konsentrasi $1592.40 \mathrm{ppm}$. Akan tetapi, satu porsi air ekstrak jahe (126 mL) memiliki kapasitas penghambatan sebesar $45.61 \%$ karena konsentrasi sampel berkisar $1226.67 \mathrm{ppm}$.

\section{KESIMPULAN}

Nilai IC50 wedang tahu lebih rendah dibandingkan tahu sutera, dengan demikian maka wedang tahu memiliki kapasitas antioksidan yang lebih tinggi dibandingkan komponen utamanya yang berupa tahu sutera. Selain itu, dalam aplikasinya satu porsi wedang tahu yang dibuat dari $80 \mathrm{~g}$ tahu sutera dan $200 \mathrm{~mL}$ wedang jahe, memiliki kapasitas penghambatan radikal bebas sebesar $74.66 \pm 5.53 \%$, sedangkan air ekstrak jahe $45.61 \pm 1.08 \%$, minuman jahe $80.65 \pm 3.91 \%$ dan tahu sutera $13.29 \pm 0.11 \%$. Dengan demikian ditinjau dari kapasitas antioksidannya, wedang tahu secara utuh lebih baik dibandingkan tahu sutera karena menunjukkan kapasitas penghambatan terhadap radikal DPPH yang lebih efektif. Selain itu, tampak adanya peranan dari komponen utama dalam wedang tahu, yaitu tahu sutera dan minuman jahe yang menunjukkan efek sinergis terhadap penghambatan radikal bebas.

\section{DAFTAR PUSTAKA}

Aspak R, Gorinstein S, Böhm V, Schaich KM, Özyürek M, Güçlü K. 2013. Methods of measurement and evaluation of natural antioxidant capacity/activity (IUPAC Technical Report). Pure Appl Chem 85 (5): 957-998. DOI:10.1351/PAC-REP-12-07-15.

Aranda RS, Lopez LAP, Arroyo JL, Garza BAA, Torres NW. 2011. Antimicrobial and antioxidant activities of plants from northeast of mexico. Evidence-Based Compl Alt Med : 1-6. DOI: 10.1093/ecam/nep127.

Awe FB, Fagbemi TN, Ifesan BOT, Badejo AA. 2013. Antioxidant properties of cold and hot water extracts of cocoa, Hibiscus flower extract, and ginger beverage blends. Food Res Int 52: 490-495. DOI : 10.1016/j.foodres.2013.01.021.

Boly R, Lamkami T, Lompo M, Dubois J, Guissou IP. 2016. DPPH free radical scavenging activity of two extracts from Agelanthus dodoneifolius (loranthaceae) leaves. Int J Toxicol Pharmacol Res 8(1): 2934.

Chen Z, Bertin R, Froldi G. 2013. EC50 estimation of antioxidant activity in DPPH assay using several statistical programs. Food Chem 138: 414-420. DOI: 10.1016/j.foodchem.2012.11.001. 
[EC] European Commission. 2010. Functional Foods. European Union (EU), Luxemburg. DOI: 10.2777/ 85512.

Giada MLR. 2014. An approach about in vitro antioxidant capacity of plant foods and beverages. Demetra: Food Nut Health 9(1): 137-146. DOI: 10.12957/demetra.2014.8256.

Gupta RK, Chawla P, Tripathi M, Shukla AK, Pandey A. 2014. Synergistic antioxidant activity of tea with ginger, black pepper, and tulsi. Int $\mathrm{J}$ of Pharm Pharmaceut Sci 6 (5): 477-479.

Han RM, Zhang JP, Skibsted LH. 2012. Reaction dynamics of flavonoids and carotenoids as antioxidants. Review. Molecules 17: 2140-2160. DOI: $10.3390 /$ molecules17022140.

Kim JK, Kim Y, Na KM, Surh YJ, Kim TY. 2007. [6]Gingerol prevents UVB-induced ROS production and COX-2 expression in vitro and in vivo. Free Radic Res 41: 603-614. DOI: 10.1080/107157607 01209896.

Murad M, Abdullah A, Mustapha WAW. 2013. Antioxidant capacity and amino acid profiles of egg tofu. Am J Appl Sci 10(11): 1315-1324. DOI: 10.3844/ajassp.2013.1315.1324.

Rodríguez-Roque MJ, Rojas-Graü MA, Elez-Martínez P, Martín-Belloso O. 2013. Soymilk phenolic compounds, isoflavones and antioxidant activity as affected by in vitro gastrointestinal digestion. Food Chem 136: 206-212. DOI: 10.1016/j.foodchem. 2012.07.115.

Shalaby EA, Shanab SMM. 2013. Comparison of DPPH and ABTS assays for determining antioxidant potential of water and methanol extracts of Spirulina platensis. Indian J Geo-Marine Sci 42(5): 556-564.
Shirin APR, Jamuna P. 2010. Chemical composition and antioxidant properties of ginger root (Zingiber officinale). J Med Plants Res 4 (24): 2674-2679. DOI: 10.5897/JMPR09.464.

Shurtleff W, Aoyagi A. 2013. History of Tofu and Tofu Products (965 ce to 2013). Soyinfo Center, Lafayatte.

Stoilova I, Krastanov A, Stoyanova A, Denev P, Gargova S. 2007. Antioxidant activity of a ginger extract (Zingiber officinale). Food Chem 102: 764-770. DOI: 10.1016/j.foodchem.2006.06.023.

Vayuphard B, Laksanalamai V. 2012. Recovery of antioxidants from grape seeds and its application in fried food. J Food Process Technol 3(4): 1-6. DOI: 10.4172/2157-7110.1000152.

Wangcharoen W. 2012. Development of gingerflavoured soya milk ice cream: comparison of data analysis methods. Maejo Int J Sci Tech 6(03): 505513.

Widyanto R, Palupi NS, Refli R, Kahfi J, Prangdimurti E. 2017. Optimization of soft tofu and ginger drink formula as components of soft tofu dessert using response surface metodhology (RSM). Int Food Res J 25(5): 1818-1828.

Yakubu N, Oboh G, Olalekan AA. 2013. Antioxidant and hepatoprotective properties of tofu (curdle soymilk) against acetaminophen-induced liver damage in rats. Biotech Res Int 1-7. DOI: 10.1155/2013/230142.

Yeh H, Chuang C, Chen H, Wan C, Chen T, Lin L. 2014. Bioactive components analysis of two various gingers (Zingiber officinale Roscoe) and antioxidant effect of ginger extracts. LWT - Food Sci Technol 55: 329-334. DOI: 10.1016/j.lwt.2013.08.003.

JMP-04-20-05-Naskah diterima untuk ditelaah pada 4 Maret 2020. Revis makalah disetujui untuk dipublikasi pada 1 April 2020. Versi Online: http://journal.ipb.ac.id/index.php/jmpi 